\title{
SIGNS OF LIFE ON A BARBAROUS FRONTIER: INTERCULTURAL ENCOUNTERS IN NORTH AUSTRALIA
}

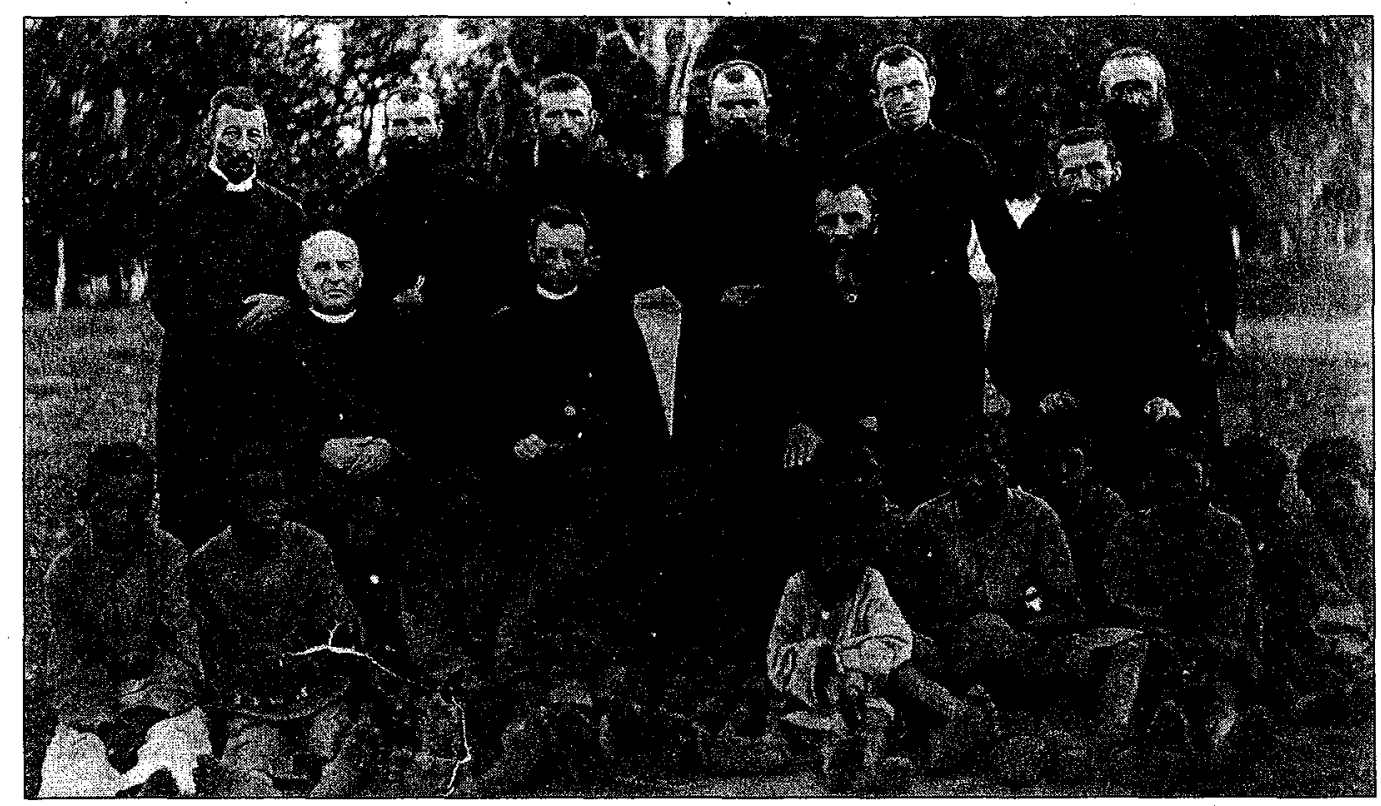

Mission staff at the Daly River Station, I8gg.

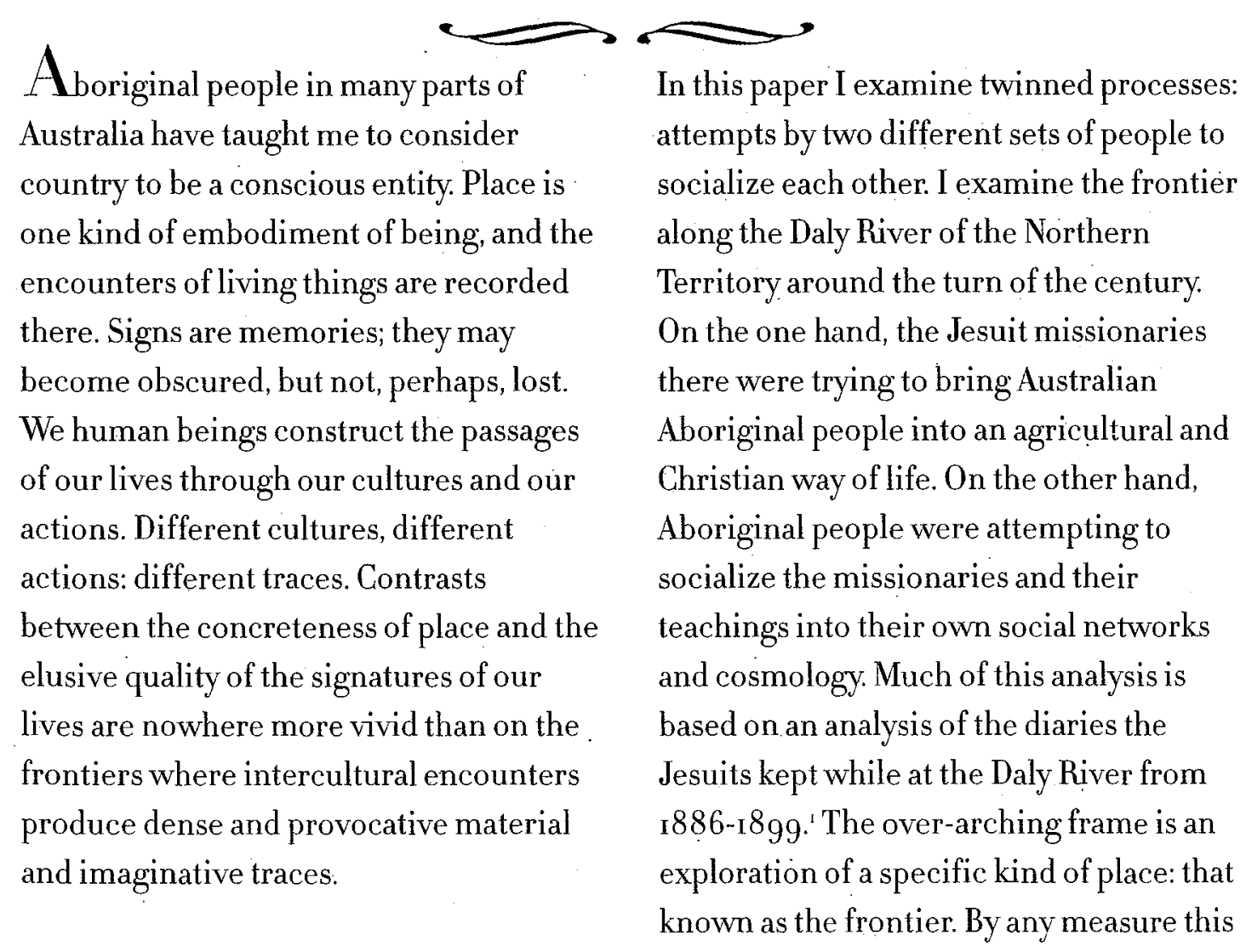


is a site of violence, since one person's frontier is, almost by definition, someone else's home, and the encounter pits a struggle for dispossession against a struggle for survival. The Jesuit diaries enable us to engage with intercultural encounters precisely at those moments when people glimpse the incommensurability of their endeavours, when contradictory and mutually exclusive efforts confront failure, and when tragedy erupts.

The tension between presence and absence is integral to western frontier ideology as it has been put into practice in North Australia. On the one hand the conquerors imagine themselves in the midst of savage people and wild places, and they construct these images around a certain moody presence signalled by adjectives such as treacherous, awesome, fearsome, happy-go-lucky, pristine. On the other hand, the savage person and the wild place are defined by the absence of civilized man (the colonizer), and thus as living absences: tabula rasa and terra nullius. Colonizing practices of the frontier deploy power and knowledge in ways that create absence where before there was specific localized presence. The imagined absence that informs colonizing practices refracts into the land and into the people to become the experience of real absence.

THE BAD AND BEAUTIFUL DALY

In I 886 a group of Jesuit missionaries trekked out to what they thought was a wild place, specifically the Daly River of North Australia, to make contact with wild savages (Indigenous people). They intended to bring to the place the civilizing influence of the cultivated garden, and to the savage the civilizing influences of agricultural labour, Christian marriage, and salvation. Central to their thinking was the view that savages were open either to corruption or to salvation, and that once corrupted they were no longer suitable material for civilization. They were thus in search of a particular type: the pristine savage. ${ }^{2}$ They imagined this type as an absence-not only the absence of their European civilization, but an absence of all civilization: a veritable tabula rasa on which they would inscribe redemption through their own cultural/ colonizing practices and through the spiritual authority of Jesus Christ.

The missionaries were to become completely disheartened. One of them went mad, others were found guilty of sexual relations with indigenous women and one was sent away in disgrace; many of their most promising converts died, and after starting afresh three times in fourteen years, the mission was closed precipitously because of a decision made overseas.

The Daly River, about I6o km south of Darwin, is inscribed in settler Australian frontier folklore as a place of massively conceived European ventures and monumental failures. According to Ernestine Hill, 'It was stark tragedy on the bad and beautiful Daly, where wily Nature 
is ever working to the defeat of man.'3

Home to 'wild blacks', site of massacres and mines, and host to a fair number of the entrepreneurial disasters so dear to Australians, the Daly is situated between the now densely settled city of Darwin and a large sparsely populated region of Aboriginal reserves.

The history of the lower reaches of the river is complex by any standard. Well before Europeans came, there was Macassan contact of some sort; the apparent introduction of the dugout canoe had almost certainly led to an intensification of social networks. From about the I86os the Darwin hinterland was occupied by settlers from a variety of cultural origins; there were Macassan trepangers, other international traders, surveyors and administrators; there were small-scale miners, both European and Chinese, as well as large-scale mining ventures; there were telegraph operators and government drillers, agriculturalists, pastoralists, and buffalo shooters; there were Chinese traders, plantations, commercial fishermen, Chinese and . European, and croc shooters; there were explorers, naturalists, police, drifters, and other adventurers with a variety of motivations; and of course there were missionaries. Aboriginal people had access not only to the standard tobacco, flour, sugar, and tea, but also to alcohol and opium. They had access not just to one set of international ideas and ideals, but to many sets, and they had ample opportunities to play the different groups off against each other; and to sample for themselves a range of ways of living.

This diversity makes for a frenzied and devastating history; in the first few decades of settlement, Aboriginal populations dropped by about $95 \% .4$ The Aboriginal people along the Daly appear to have been similar to other Aboriginal people in their responses to white invasion. On the one hand they fought Europeans and Chinese, and on the other hand they attached themselves to them for protection, for political advantage, and as a source of tobacco and other exotic items. ${ }^{5}$ Little is known of the earliest years. Sowden notes that at Owston's sugar plantation 'the blackfellows give very little trouble now. They did at first--they stole all the stores, but they were punished for it. ${ }^{\prime}$ Punishment was likely to have taken the form advocated by the proponents of extreme violence - an indiscriminate slaughter of men, women, and children.

Carried out periodically over large areas, such actions had the effect of drastically reducing Aboriginal populations and demoralising Aboriginal people for decades. The Coppermine massacres of I 884 are a classic example of the search and destroy method of settling country. Several Aboriginal men who were working with white men at the Coppermine near the Daly killed four white men. If, as seems likely, there was a European trigger to the initial violence, it is now obscure. As soon as the word got out, police and civilian volunteers armed themselves to track down and destroy the 
murderers. According to Morice,

Protector of Aborigines at the time, the 'general belief in the Territory was that they simply shot down every native they saw, women and children included'? Subsequently, diseases devastated local people. The Jesuits witnessed radical population decline, but seemed only to realise the implications of what they were seeing toward the end of their stay.

Such was the situation when the Jesuits arrived: there were European and Chinese settlers, market gardens, plantations, cattle stations, mines, massacres, and commercial fisheries. Their imagined wilderness was an illusion even by their own criteria. The Jesuit writings, and the perspicacious observations of the Norwegian naturalist Knut Dahl, provide an incomparable record of a thin slice of the intense social life on the Daly just before the turn of the century. ${ }^{8}$ Since that time the most acute observations have been those of the anthropologist W.E.H. Stanner who was there in the 193 os and r $95^{\circ}$ s. Aboriginal people were then clustered on farms run by settlers in harsh degrees of poverty; daily life was shot through with violence and degradation. Stanner wrote: 'The river seemed to me a barbarous frontier - more, a rotted frontier with a smell of old failure, vice, and decadence.' 9 As I will discuss in greater detail, he found Aboriginal people in a state of desperate dependence, the authority of the old people in decline, bush tucker scarce, and many people in a state of spiritual crisis or despondency.
In recent years much of the land has been returned to Aboriginal people's control under the Aboriginal Land Rights (NT) Act ${ }^{2} 976{ }^{\mathrm{ro}}$ Stanner's pessimism regarding people's loss of cultural connections to land and law has been overridden by Indigenous bonds of connection. I came into contact with the region through my role in assisting Aboriginal groups in land disputes. At least two major disputes about land among Aboriginal people in the Northern Territory have their roots in the social dynamics of the missionary period at the Daly. I have searched all the Jesuit records available to me for information that might assist in understanding the complex history which underlies these disputes.

In 1998 the Daly retains its reputation as a frontier region. It is home to 'feral' whitefellows, pig shooters, weekend fishermen, and settler entrepreneurs. Although the Jesuits left in I 899 , they returned in 1955 to establish a mission settlement called Nauiyu Nambiyu. The Port Keats mission, some I6o kilometres to the south west, was established in $1935^{1{ }^{1}}$ Both of these mission settlements remain in place today. Aboriginal people live in and travel between a number of settlements and outstations.

\section{SETTLEMENT AND SOCIALITY}

At the time of invasion Aboriginal people were organized into local groups interlinked within a regional sociality. Regional networks brought people into relationships through marriage, 
reciprocity for subsistence organized through mutual foraging rights, and shared responsibilities in religious ritual. All the dimensions in which sociality was fostered came together in the context of land. Rituals were organized around seasonal abundance and celebrated sources of life; marriage, dispute management and religious law and authority were organized, celebrated and regenerated in ritual. In this section I discuss missionary endeavours taking land as the focal point. In the following section I will explore the religious encounter along this frontier of the soul. I do not pursue the issue of marriage. Suffice it to say that the missionaries opposed arranged marriages, and to the extent that they disrupted marriages, they also disrupted the authority of senior men and women. At the same time, their own surreptitious sexual exploits appear to have led local Aboriginal people to consider that the missionaries were trying to marry into the group. On the part of Aboriginal people, there would have been an expectation of reciprocity, while on the part of the Jesuits there was an expectation of submission. All were disappointed.

Many of the missionaries were Austrian; they came to a continent that was foreign to them, and then to a region of the continent that was supremely foreign. One of the most evocative lines from the diary is the description of the Daly River which, the diarist notes with distinct melancholy, looked nothing like the Danube. It had, he proclaimed, 'a soft, soapy taste, like an extract, as it were, of alligators.'

Their intention was to establish a centre to which people would come in order to settle permanently. They followed the model of missionization that had been developed in South America: that of developing self-sufficient agricultural settlements. Knut Dahl commented wryly on the Jesuits' goal of introducing agriculture to Daly River Aborigines:

Let us, the Jesuit argues, first of all persuade these savages to give up their roving life, let us teach them to cultivate the soil, and let us make them understand that their work in this way brings them greater happiness, makes them more care-free than their old life. Then possibly their progeny, the new tribes of settled agriculturalists, may be more susceptible to our religious propaganda. ${ }^{\text {I2 }}$

The missionaries complained regularly about the mobility of the people they were trying to convert: 'almost every day new listeners take the place of those who preceded them. [And] ... when they come back are as if they had never heard anything about Christianity.' ${ }^{\mathrm{I} 3}$ Missionaries and Aborigines were operating in very different social and geographical worlds. Missionaries effectively inhabited one place-their mission. They made forays into the surrounding country, and some of them were far more mobile than others, but they almost invariably travelled with mission Aborigines. Their close relationships were always with the very 
small group of people who, at any given time, formed the nucleus of the settlement. ${ }^{14}$ Aboriginal people, in contrast, lived in and through a far more complex set of geographical, social, and cultural worlds. They camped in many places and periodically visited many institutions of which the mission was only one, and probably a minor one. They were in and out of the mission at a great rate; they had their home countries, their regular ranges (countries where they had various types of rights), and a variety of settlement sites which included the mission, the Coppermines, the Chinese gardens, farms and cattle properties, railway sidings and more. Their social world included Chinese and European miners, Chinese traders, settlers, police, and travellers, as well as all the Aboriginal people of the region with whom they had ties of marriage, trade, and ceremony (including peoples from coast and inland, from north and south). ${ }^{5}$ There was an ongoing social and religious life that was totally external to the missions, and which the missionaries sought to stamp out.

The purpose of the mission, as stated, was twofold: to achieve independence from major external support (funds were always a problem), and to teach the Aborigines the meaning of property, labour, and submission to mission authority, by inducting them into an agricultural form of production. There is a pattern to the missionaries' endeavours. Time and again they drummed up a bit of enthusiasm, praised the Aboriginal people for their work, watched them slack off, completed the work themselves, and attributed the completed work to the Aborigines. This form of self-delusion led to some bitter remarks toward the end, but on the whole it seems to have been a successful strategy-not so much to encourage the Aborigines as to encourage the missionaries.

A series of entries shows Fr Kristen engaged in this process:

$14 / \mathrm{i} / 88$ Charlie is given garden at Hunger Hill to look after. ${ }^{16}$ He wants to live there.

$\mathrm{r} 8 / \mathrm{x} / 88$ Charlie is given seeds to plant shortly thereafter: 'Charlie has already sowed a part of his garden, he will finish it next week. It is a most commendable effort for this barbarian, unaccustomed to toil, and accustomed to unbridled freedom.' ${ }_{27} / \mathrm{I} / 88 \mathrm{Fr}$ Kristen finished sowing Charlie's garden.

In addition to the agricultural program, Aboriginal mission people were also encouraged to build houses. Here again, $\mathrm{Fr}$ Kristen assisted:

II/2/88 Charlie has put up two huts at Hunger Hill, one for self and Zachary, another for Jacky and Albert.

14/2/88 Fr Kristen roofing Charlie's huts. 2I/2/88 Fr Kristen built a fence around Charlie's hut.

At the end of the year Fr Kristen was still at it:

24/12/88 Fr Kristen helping Zachary \& Billy to build their houses 26-7/12/88 Kristen putting roofs on native huts. 
There is also the story of the missionaries' attempts to establish their own gardens, which is itself remarkable. O'Kelly summed up the last few years, and they are typical:

In ' 92 a plague of caterpillars necessitated a double sowing of maize; in ' 93 a visitation of rats made it necessary to plant the African corn four times and reduced the harvest to six tons; in ' 94 the ravages of field mice meant that some fields had to be sown three times, and then reeds sprang up and ruined many acres; in ' 96 birds reduced the corn harvest to three tons ...; in ' 97 intense heat defeated their irrigation and reduced an expected six ton crop of corn to two; in ' 98 the first flood devastated all crops and gardens and the same occurred in ' $99 .{ }^{17}$

These problems ignore all the human factors. Aboriginal people regularly took food from the gardens rather than storing it (often termed 'theft' by missionaries), and regularly destroyed gardens as an expression of anger directed toward the missionaries or toward each other.

The missionaries' fluctuating ability to support Aboriginal people constitutes one of the most contradictory aspects of their endeavour. When they were flush with food they attempted to bring people in, impose Christian morality on them, and induce them to give up their own way of life in favour of an agricultural mode of subsistence. Thus, for part of almost every year of the whole fourteen years, Aboriginal people were thrown back on regional subsistence and social networks because the mission simply could not support them. A plaintive entry in the I8go diary hints at the Jesuits' frustration at their inability to accomplish their sedentarizing project:

They will not stay, however, unless they are supplied with food, they cannot get enough native food for themselves in this region which is largely destitute of it, ... we lack money and certainly will lack money in the future. $[22 / 4 / 9$ o]

From an Aboriginal perspective it would have been completely self-defeating to make a comprehensive social and subsistence commitment to the missionaries. Given that most Aboriginal people could not survive throughout the year with the missionaries, they had to sustain their relationships to other Aboriginal people and to other settlers. The mission was incorporated into Aboriginal social networks as one more centre where people could go for greater or shorter periods for a broad range of purposes, many of which undoubtedly were incommensurate with missionary purposes.

At the same time that the mission was being incorporated into Aboriginal networks, so too were the missionaries. They studied the local Malak Malak language in order to communicate their Christian message; more importantly, local knowledge enabled their own survival. Throughout the whole period the missionàries were dependent on local native foods. Their range restricted by their investment in and commitment to their settlement and their gardens, they 
developed a form of settled hunting and gathering that had clearly detrimental effects on the environment. In 1892 the diarist notes the amount of native game obtained up till August of that year: they had shot $55^{\circ}$ kangaroos, 6oo geese, 30 pelicans, $5^{\circ}$ ducks. The regular mention of cartloads or boatloads of yams and yillik (corms of the lotus lily, Nelumbo nucifera) indicate tons of food being brought in, and Fr Mackillop's comment that lily seeds pickled in brine are quite tasty suggests that they were harvesting surpluses for storage..$^{18}$

As table I shows in detail, year after year the reliance on bush tucker continued. The results were predictable: regular resource areas close to the mission were over-taxed and became sites of contention. Aboriginal people relied on these resource sites for their subsistence, and organized ceremonial events to take advantage of local abundance, only to find that there was no such abundance.

In the short term, the effects of settled hunting and gathering were noticeably destructive. In the long term the missionaries' impacts were only a small part of a much larger set of colonizing practices. Today, feral pigs have turned over virtually every square inch of the rich Daly swamps, like Nanerain and Pangerain. The noxious weed Mimosa pigra is invading the water systems (and during part of the year vast portions of the region are covered with water); it favours ground from which the vegetation has been disturbed. ${ }^{9}$ Both pigs and Mimosa pigra are out of control. In 1998 the future of these homelands looks bleak.

\section{TAMING THE CROSS}

The missionaries vigorously opposed Indigenous religious practice. In their own accounts they express their theological and practical opposition to Indigenous religion. People were punished for participation in ceremony, and were not allowed to observe taboos or other markers of ritual status at the mission. The diaries are full of references to punishment, but rarely is the mode of punishment stated. Beatings and floggings were regular occurrences, and threats of the punishment of God were also indicated, as in this entry concerning the death of a senior man named Bede:

Nine weeks ago Fr Conrath told this man not to go to the 'Karamala', which is a pagan festival, threatening him with the punishment of the Almighty God if he did go. 'I shall go', said the native, 'let God punish me'. [3/8/98]

The quirky manuscript that Fr Kristen wrote while he was recovering from nervous exhaustion offers glimpses of how Aborigines perceived Christian teachings. He informs us that the Aborigines had formed a punitive view of the crucifixion: Of course Fr Conrath spoke mostly on divine mysteries under the cross, the great mysterious sign on the hill. Some Blacks 
thought that.cross was for hanging them up if they would not yield to his counsels .... ${ }^{20}$

This interpretation of the cross seems certainly drawn from the floggings and other missionary actions. In addition, of course, random violence and all the punitive expeditions and dispersals by other settlers and police contributed to people's understandings of colonization. The quality of mercy was never conspicuous on the frontier; images of a punitive god were given flesh by people's own experiences.

Fr Kristen goes on to tell us that Aboriginal people were querying the social and theological implications of the Christian myth:

In the year I 893 after the usual Sunday instruction in New Uniyah, when I had read and explained the parable of Our Lord, if I remember well, it was the 7 th Sunday after Pent. an old man ... came to me and inquired earnestly whether that Master Jesus was a Mallac [Malak], one of their own brown race? ${ }^{21}$

The punitive character of the cross and the story of an Aboriginal Jesus, almost certainly were combined in another ritual which appeared to Fr Kristen to invert Christianity so violently as utterly to defile it. The ritual was called Tyaboi, and Fr Mackillop wrote:

I am about to make a strong assertion; but I believe it to be true. I believe they have human sacrifices, that from time to time one man, with his own knowledge and consent, is offered in sacrifice for the good of his people - offered to the evil spirit whom they so fear. This is the leading feature in the great religious and highly immoral ceremony, which they celebrate every few years. They call it Jaboi. ${ }^{22}$

Mackillop is incorrect. There are absolutely no reports of human sacrifice among the Aboriginal people of Australia, nor are there, to my knowledge, any practices that could reasonably be misinterpreted as human sacrifice. Fr Mackillop's account of Tyaboi is so clearly an account of Christianity that I would suggest that the 'evil spirit' is likely to be God himself: the Father who killed his own son and who, through the missionaries, threatened to kill other men as well. In short, the evidence suggests that the missionaries introduced to the Aborigines of the Daly the concept of human sacrifice to a punitive God.

Fr Kristen recorded in the diary:

'Tyaboi' begins, and the fight of the devil with Christ for the blacks. Benbenyaga (blacks), Chinese garden, Chinese, Coppermines, all mixed up in it - so we have heard from a Christian boy sufficiently grown up to know ... [17/ $\mathrm{ro} / 93]$.

On this evidence Tyaboi can be identified as a contact cult, incorporating that which is new and relatively unknown within an indigenous cosmology-to tame, socialize and gain control over that which is wild, unpredictable, and unmanageable. In colonizing contexts, contact cults have an unruly and imaginative capacity to mirror, mimic, transform, destabilize, 
deconstruct, parody and politicize the colonizers and the worlds of ideas and material goods they drag along with them. ${ }^{23}$

The purposes of Tyaboi would have included that of giving the new people, places and experiences of colonization a place in the indigenous cosmology. Fr Kristen tells us of the Chinese, the gardens, the Coppermines and the Aboriginal people. What he does not tell us, but what an anthropological reading assures us, is that the missionaries too would have been included in Tyaboi. The ritual would almost certainly have included long black robes, and mumbo jumbo in pidgin Malak Malak to mimic the missionaries' attempts to preach in language. There would have been crosses and odd gestures mimicking communion and other Christian rituals and symbols. There would, in short, have been evidence which for Fr Kristen would have confirmed his fears that Satan was alive and well right there on the Daly.

In sum, Tyaboi seems to have been a ritual designed to tame the punitive practices of the cross, to socialize the missionaries within a regional Aboriginal cosmology, and to bring into being the reciprocities that the missionaries and all the other newcomers on the Daly so constantly refused. Fr Kristen's discussion of the language of evil includes both his story of a man's question about an Aboriginal Jesus and the term for the 'evil spirit' of indigenous cosmology: 'Jin-man'. The term resonates with Chinaman, and although that may be an accident, it has a long and disruptive history, as we will see.

\section{THE END}

The mission was brought to an abrupt and unexpected end in mid-1899 by a decision made by the European Superiors. ${ }^{24}$ By I899 the mission consisted of a large house, a church and school, dormitories, native houses, stables, a printery, granary, and steam engine for the irrigation system. There was a sawmill, wells, pipelines, sheds, stores, and forges. The mission had 2,ooo goats, $15^{\circ}$ cattle, 130 pigs, and 33 horses. ${ }^{25}$ And then, over a period of a few days in July 1899 , the Aborigines were dismissed, the buildings they had helped to construct were dismantled, and the livestock they had helped herd were sold off. I would guess that the irrigation was cut off to the gardens they had worked as their own. In short, the work of their lives was put up for sale. The former mission was purchased by a well-to-do cattle baron; gardens, irrigation, buildings, livestock - all the product of the labour of Aboriginal people (along with the missionaries) became the property of others.
Absence thus comes full circle, from terra nullius and tabula rasa, through a dialectic of ecological practices that devastated the land and failed to provide a living. The glimpses we have of the life of one of the senior Aboriginal men of the region, Daly, illuminate the exchanges, reciprocities, failures of reciprocity, and, from a 
missionary perspective, the final expendability of Aboriginal people. Daly was one of the law men of the region. $\mathrm{He}$ had been arrested and tried for murder in conjunction with the Coppermine killings of 1884 , and had been acquitted. ${ }^{26} \mathrm{~A}$ few years later he became one of the missionaries' great allies. Daly recruited people, built huts and planted gardens, and like the others he came and went.

Although he had promised one of the missionaries to refrain from participating in his own religious rituals, he must have continued his participation, because the missionaries took a set against him. In January i 890 (wet season) he came to the mission very ill and seeking admission:

Daly is in a wretched state, we have judged it better not to admit him to the station because of his hard obstinacy and deceitful character, on the other hand we cannot reject him and expel him by force. He now lies sick out in the open, with his whole family, with no food except what his wife Jinny brings him every day. He has asked whether he is soon going to die. $[\mathrm{ro} / \mathrm{I} / \mathrm{go}]$

On the $3^{\text {th }}$ of the month the issue was decided:

The wondrous Providence of God intervened to remove a great impediment to our work by taking Daly from this life. [I $3 / \mathrm{I} / 9 \mathrm{o}]$

The missionaries refused him a Christian burial, so his own people were free to take his body back to his own country, to the swamp called Woenelen where he was buried in traditional fashion. The place today, like other swamps, is completely rooted up by pigs.
The secular press in Darwin was quick to label the mission a failure, implying that it had little impact on the Aboriginal people, and subsequent discussions tend to reinforce this position. And yet missionaries attempted to suppress initiation ceremonies for young women and men, they attempted to suppress other religious activity, they intervened in mortuary rites, they altered marriages, altered authority relations, and had a noticeable impact on the environments on which they depended. To sum this up as a failure to have an impact, or to assume that the impacts had only been superficial, is to set up the parameters of the frontier: presence disguised as absence. Denial of impact was also a denial of accountability and responsibility. The missionaries and everyone else could rest assured that their departure had no consequences because their presence had had no effects.

\section{SPIRITUAL TRACKS}

Yet some Aboriginal people took the Jesuit teachings seriously, seeking to engage with them on a spiritual/theological level. I now turn to this engagement. When Stanner got to the Daly in the early I $93^{\circ}$ he encountered a people who were in a state of spiritual despondency. The story of how that came to happen occupied his mind and heart, and his best writings come from his attempt to understand the pain, anger, and emptiness that he felt his close friends were experiencing, as well as their exhilaration at encountering a new revitalising cult. ${ }^{27}$ My focus on the 
missionaries leads me to emphasize their impacts, but it must be clear that the social conditions Stanner described were brought about by the broader regimes of frontier violence discussed previously. According to Stanner, in $193^{2}$ local Aboriginal people had a cultural myth that was in its heart an inversion of the Christian Father and Son. He noted that the two traditions (Christian and local Aboriginal) were 'remarkably parallel institutions about man and his whole situation'. He held the view that there was 'no historical connexion whatever'. ${ }^{8}$ I will suggest, of course, that there was an historical connection, and that the two parallel stories were not only about 'man' but also about the Jesuit presence and absence, and thus about local Aboriginal people's prior experience of colonizing Christianity.

In summary form, the myth tells of a great man, Angamunggi, who was killed by his son. The son was named Tjinimin; he seduced his sisters, and then speared his father, while Angamunggi was engaged in religious ritual. The father lived long enough to generate sources of life: permanent fresh water pools, where he left the spirits of the unborn. 'One patrilineal moiety called him "father's father", the other moiety called him "mother's father". Sometimes he was called by both moieties Yila Neki, the Father of Us All'. ${ }^{29}$

Stanner proceeded to uncover a universal spiritual and moral content of this myth. I propose to look at it in its precisely local context. The name 'Tjinimin' seems clearly related to Fr Kristen's Jin-man, and may also be related to 'Chinaman'. As such, he is a cult hero, or an amalgam of cult heroes, and is connected to what we know of Tyaboi, although by Stanner's time Tyaboi was no longer part of the spiritual life of the Daly. The Father/Son myth tells of the son named Tjinimin who creates absence: it speaks of a failure to nurture, a failure to reciprocate, a failure tọ observe sexual rules. These characteristics clearly mark the missionary endeavours as they are likely to have been perceived by those Aboriginal people who cared enough to take them seriously.

Table 2 is an attempt to discern within a myth collected in the r 93 os a temporally distant narrative of the i886-I899 experience. The left-hand column repeats Stanner's account of the myth; the righthand column, while lacking artistry, seeks an historical structure within the myth.

We can read this terrible myth of patricide as the missionaries' attack on indigenous religious law: 'Angamunggi sat ... at song and music during a festive gathering of all the clans'-he could have been Daly, or any of the Aboriginal people who worked so hard to keep their culture alive while accommodating invasion.

In his I959 essay, Stanner tells us something of what had befallen this myth: In the I 920 a widespread conviction had grown up on the Daly River that their own culture-hero, Angamunggi ... had deserted them. Before I had heard a word of Kunabibi 
[a religious movement referred to by some as the All-Mother] I had been told that Angamunggi had 'gone away'. Many evidences were cited that he no longer 'looked after' the people: the infertility of the women..., the spread of sickness, the dwindling of game among them.$^{30}$

A cosmological absence had erupted on this barbarous frontier. An emptiness lurked in the country itself, and in the hearts and minds of its people. Stanner's words suggest that Daly River people had examined their current situation, as if in a looking glass, and had come to the theological conclusion that their lifegiving Father (Angamunggi) had abandoned them. The evidence was the loss of life-human life, animal life, and life support systems, the signs of which already were visible in the Jesuit diaries. Life, one might say, was trickling out of the country, and the waters of life no longer seemed perennial..$^{3}$

Anthropologists Ronald and Catherine Berndt made a similar assessment in 1946 when they spent a few months on the Daly and collected some stories from a man named Matthew Melbyerk who had been with the mission when he was young. ${ }^{32} \mathrm{His}$ account of 'The Allocation of Food by Jesus' describes the relationships pitilessly. It begins with an account of Jesus feeding his apostles apples (in neverending abundance), after which they made and ate other foods:

So they returned to their garden. Later they grew wheat, and made flour. Then Jesus made a big damper. When it was ready, they all sat down at the long table and they ate of this damper until they were full. But they did not finish it: Jesus put it away, as he had done with the apple.

And the Father talked to Jesus: 'All of this is for white men-they will have iron, houses and everything.' Thus the Baijang [Father] put motorcars, aeroplanes, houses, horses and so on for all the white people; he also made rifles, guns, pannikins and knives; and Baijang spoke to Christ, "That is the Dreaming for all of you lot.' Jesus Christ was on the side of the white people--he gave all that food to them. Adam had only native food, for Adam and Riva [Eve] were Aborigines. They had nothing when they left the garden owned by God.

Chinamen grew rice and made grass houses: white men saw these, and the Chinamen saw the iron houses: the white men saw the rice, and the Chinamen saw the flour: each bought from the other. Only the Aborigines had nothing. ${ }^{33}$

Australian Aboriginal people's stories of this type (generally classed under the label 'cargo cult') are only incidentally about material wealth, while in their heart they search for moral relationships between settlers and indigenous peoples. ${ }^{34}$ The story of Jesus's allocation of food vividly conveys a people's sense of looking at themselves as if from afar, objectifying themselves as a set of absences and losses. It also conveys with brutal force the failure of reciprocity: 'each bought from the other. Only the Aborigines had nothing.' The attempt to transform the wild place and the wild person into civilized place 
and civilized person was an attempt to fill an emptiness with culture; it resulted in the creation of emptiness.

The colonizer denies that his actions have enduring effects. Spiritual traces tell another story. Quite provocatively, Jinman/Tjinimin seems to have been carried to other parts of Australia, probably through transformations and exchanges of Tyaboi and related rituals. It is possible that Fr Kristen's teachings were later to arise, transmogrified but still wildly appropriate, in other frontier situations. The anthropologists Petri and PetriOdermann were in Western Australia in the 1960 s, and they report the rise of a new cult centred on 'Jinimin-Jesus' 35

According to what they were told, Jinimin revealed himself to the Aborigines in the east. He had both black and white skin colour, but his message was for Aboriginal people: 'Jinimin had proclaimed that all the land had from the beginning belonged to the Aborigines and that in the future there would be no differences between Aborigines and other Australians-all would share equally in that land' $3^{6}$

Petri \& Petri-Odermann call this ritual complex the Jinimin religion, and they report that Jinimin is said to have stated that Aborigines could only bring about this desired state of affairs by adhering to their own traditional Law. He was said to have revealed himself while people were singing song cycles of the Law known as Worgaia, also known as Gadjeri. ${ }^{37}$ This Law is the same as the 'All Mother' cult which
Stanner encountered in the r 930 s and which he describes so eloquently in his portrait of Durmugam..$^{8}$

I hear this echo: Angamunggi can sing again, and the land can be restored.

Jinimin, I suggest, is a transformation of Tjinimin and Jin-man, metamorphosed through successive exchanges and performances. (Recall that Fr Kristen recorded the term Jin-man in his discussion that included questions about an Aboriginal Jesus.) I suggest further that while Western Australian revitalization cults have their roots in numerous missionary sites (the Daly Jesuits were not, of course, the only missionaries in Australia), the term Jinimin, signifying Jesus, clearly links the Daly of the I 8 gos with Western Australia in the rg6os through a path we cannot properly detect. ${ }^{39}$ Aboriginal people in. Western Australia speak of restoration through Dreamtime action:

The return of the Dreamtime beings ... to their original territories took place expressly on the orders of Jinimin-Jesus (or Our Lord Himself). They march on the underground routes, using camels which carry their belongings including the cult objects..$^{\circ}$

These Dreamtime Magi who travel underground-toward what devastated homes do they trek? And will they regenerate life, land, and law?

The missionaries offered a promise of life, and delivered a punitive god who demanded human sacrifices. They delivered a blow to Indigenous Law, along 
with an objectifying awareness of loss and failure. From my western perspective, most of the signs of the passage of their lives are places where the waters of life are drying up-a wilderness of invading settlers, pigs, and weeds. But from an Aboriginal perspective it is possible that conquered space is not empty. Stories of Jinimin and the Dreaming speak of an imagination sharpened and expanded by the experience of the most barbarous of frontiers; they offer evidence of a continuing spiritual presence and an indigenous promise of life. $\propto$

DEBORAH BIRD ROSE

Deborah Bird Rose is a Senior Fellow at the NorthAustralia Research Unit. 


\begin{tabular}{|c|c|c|c|c|c|c|c|c|c|c|c|c|}
\hline & JAN & FEB & MAR & APR & MAY & JUN & JUL & AUG & SEP & OCT & NOV & DEC \\
\hline $8_{7}$ & & goose eggs & & & & & & & & & & \\
\hline 88 & \begin{tabular}{|c|} 
geese \\
kangaroos \\
fish
\end{tabular} & & fish & eggs & hunting & . & & & & & & fish \\
\hline 89 & & & $\begin{array}{l}\text { goose eggs } \\
\text { fish }\end{array}$ & & & & & & & & yillik & \\
\hline $9^{\circ}$ & & & fish & & $\begin{array}{c}\text { fish } \\
\text { kangaroos }\end{array}$ & & $\begin{array}{c}\text { dirualk } \\
\text { (nuts) } \\
\text { kangaroos }\end{array}$ & valangerk & yillik & & famine & famine \\
\hline $9^{I}$ & & & & . & & & & & yillik & yillik & $\begin{array}{c}\text { yillik } \\
\text { finishes, } \\
\text { nain }\end{array}$ & nain \\
\hline $9^{2}$ & $\begin{array}{c}\text { yillik } \\
\text { dimggeri }\end{array}$ & & & yams & & net fishing & $\begin{array}{c}\text { famine } \\
\text { yillik } \\
\text { hunting } \\
\end{array}$ & $\begin{array}{c}\text { yillik } \\
\text { (stressed) } \\
\text { at Nanerain }\end{array}$ & $\begin{array}{c}\text { yillik fish } \\
(\text { Pangerain) }\end{array}$ & - & famine & \\
\hline 93 & . & & eggs & $\begin{array}{c}\text { goose eggs } \\
\text { yams }\end{array}$ & & & & & & & & famine \\
\hline 94 & & & eggs yams & $\begin{array}{c}\text { wild } \\
\text { potatoes }\end{array}$ & & & & & & fish & & famine \\
\hline 95 & & $\begin{array}{c}\text { goose eggs } \\
\text { yams }\end{array}$ & $\begin{array}{c}\text { goose eggs } \\
\text { yams }\end{array}$ & yams & & & & & & & $\begin{array}{c}\text { yams } \\
\text { sprouting, } \\
\text { yillik }\end{array}$ & \\
\hline $9^{6}$ & & goose eggs & . & & & & & & yams & $\underset{\text { tortoise }}{\operatorname{yams}}$ & yams & \\
\hline 97 & yams & yam eggs & eggs & yams & yams & yams. & yams & yams & \begin{tabular}{|c} 
yillik, yams, \\
getting \\
scarce
\end{tabular} & . & yams & \\
\hline $9^{8}$ & & & goose eggs & & first yams & & & yams & yams & & & \\
\hline 99 & & & eggs & yams & & & & & & & & \\
\hline
\end{tabular}


Table 2: Angamunggi and the Missionaries

A great man, Angamunggi,

was treacherously

killed by his son,

who had committed incest

Angamunggi's daughters.

The girls were trusting and,

we may presume, innocent.

The son, Tjinimin,

was filled with guile, malice and lust.

Having seduced his sisters,

he next speared his father,

while Angamunggi sat

unsuspectingly, surrounded by

his many children, at song and

music during a festive gathering

of all the clans.

The father, in agony and about to die,

lingered on to perform a series

of marvels [forming a sacred track].

At each resting place he tried

unavailingly to staunch the flow

of blood from the spear wound

in his side [creating permanent

fresh water pools, and leaving

the spirits of the unborn within them].

...Now, Angamunggi ... is conceived

of as man, an immense man of great

powers ... One patrilineal moiety

called him 'father's father', the

other moiety called him 'mother's

father'. Sometimes he was called

by both moieties Yila Neki,

the Father of Us All.
Senior men (Daly, for example),

were

killed by the missionary figure

who had had sex

with Aboriginal women,

including young women in their care.

The missionary figure

(filled with guile, malice \& lust)

attacks senior Aboriginal men

(explicitly defined as such)

Senior Aboriginal men take on

an attribute of the crucified Jesus

(once thought perhaps

to be a Malak Malak man),

as well as the qualities

of a culture hero.

Jesus and senior Aboriginal men

explicitly brought into one embracing

set of social imagery; defined as

explicitly Aboriginal. 


\section{ACKNOWLEDGMENTS}

I owe a special debt to a number of generous and open-minded Jesuits, particularly $\mathrm{Fr}$ Greg 0 'Kelly, historian and teacher, and Fr Tom Daly, Archivist at the Provincial Office, Melbourne. Britte Duelke has spent years living with and working with Daly River people, and my appreciation of Daly River culture was sharpened by conversations with her. Darrell Lewis assisted me throughout, and especially in the field portions of the research; Kimberley Reid brainstormed with me at a crucial moment; Robin Torrens offered valuable suggestions on an earlier draft. I thank all three, along with the anonymous referee with the red pen. Earlier drafts of this paper were presented to the European Association for Studies on Australia Conference in Copenhagen (I995) and to the NT Historical Society; many people gave me warm and provocative feedback for which I am grateful. Thanks to Jenny Green for the table of bush foods. The photographs at the beginning of the article and on the cover are reproduced by permission of the Australian Province of the Society of Jesus.

\section{NOTES}

'Translated into English from the original Latin by P. Dalton, and held in the Archives of the Jesuit headquarters in Melbourne, Victoria.

${ }^{2}$ Alroe's comments on this point are insightful. See M. Alroe, 'A Pygmalion Complex Among Missionaries: The Catholic case in the Kimberley', in T. Swain \& D. Rose (eds), AboriginalAustralian and Christian Missions, The Australian Association for the Study of Religions, Bedford Park, South Australia, 1988 .

${ }_{3}$ Hill, E., The Territory, Walkabout Pocketbooks, Ure Smith, Sydney, I970 [195I], p. 28 o.
${ }_{4}$ See I. Keen, The Alligator Rivers Stage II Land Claim, Northern Land Council, Darwin, I 980.

5 The addictive quality of tobacco seems to have been seriously underestimated in analyses of black-white relationships. A good corrective to this view is P. Read \& E.J. Japaljarri, 'The Price of Tobacco: The journey of the Warlmala to Wave Hill, 1928 ', Aboriginal History, 2 (2), 1978, 141-8. W. Stanner ('Continuity and Change among the Aborigines' (1958) in White Man Got No Dreaming: Essays 1938-73, Australian National University Press, Canberra, 1979, $4 \mathrm{I}^{\mathrm{I}}$ 66) is one of the few who gives credence to Aboriginal people's own statements: 'The evidence, and discussions with natives who had lived there as children [in the bush], satisfied me that the Aboriginal explanation is correct. They say that their appetites for tobacco and, to a lesser extent, for tea became so intense that neither man nor woman could bear to be without.' (p.47)

${ }^{6}$ Sowden, W., The Northern Territory As It Is. reprinted by the Grovernment Printer of the Northern Territory, Darwin, 1882, p. 107.

7 Quoted in A. Markus, From the Barrel of a Gun: The oppression of the Aborigines, $1860-$ Igoo, Victorian Historical Association, Melbourne, 1974 , p:I 8. Morice was subsequently removed from his job because of his attempts actually to protect Aborigines.

${ }^{8}$ Dahl, K, In Savage Australia, Philip Allan \& Co. Ltd, London, 1926.

9 Stanner, W., 'Durmugam: A Nangiomeri' (I959) in White Man Got No Dreaming, 67-105, p.8o.

${ }^{10}$ See P. Sutton \& A. Palmer, Daly River (Malak Malak) Land Claim, Northern Land Council, Darwin, 1980 and Aboriginal Land Commissioner, 'Daly River (Malak Malak) Land Claim', Report by the Aboriginal Land Commissioner, Australian Government Publishing Service, Canberra, 1982 . Britte Duelke's anthropological research and 
linguistic research by Ian Green, Mark Harvey and Nick Reid all are contributing to the written record of the region.

${ }^{"}$ Forrest, P., The Spirit of the Daly, Daly River Community Development Association, Daly River, 1994, pp. 68-69 and Pye, J., The Daly River Story: a river unconquered, Colemans Printing Pty, Darwin, $19{ }_{3} 3$ [1976].

${ }_{12}$ Dahl, In Savage Australia, p. 36. Dahl expected that the missionaries would fail in Australia, and although he attributes the failure primarily to mysterious forces within the Aboriginal people, he noted that cultivation was not enabling a more carefree life (p. 37)

${ }^{13}$ Quoted in G. O'Kelly, 'The Jesuit Mission Stations in the Northern Territory $188_{2}$ I899', BA Honours thesis, Monash University, Melbourne, 1967 .

${ }^{14} \mathrm{At}$ the time of their last census, the missionaries claimed 219 Christian natives, 39 of whom were at the station, and 180 of whom were in the bush. These figures can be contrasted with other census reports, and while it is clear that the numbers fluctuated enormously in relation to the numbers of settlers in the region (more settlers, more Aborigines). H. Brown reports an estimate of Iooo Aboriginal people in the vicinity of the Coppermines in 1905 (Reports (Geological and General) Resulting from the Explorations made by the Government Geologist and Staff during 1905, Government Printer, Adelaide, I906, p. 38).

${ }^{15}$ Dahl, In Savage Australia, p. 24, rog-ıı.

${ }^{16}$ The hill is immediately adjacent to the first site at Uniya.

${ }_{7}^{17}$ O'Kelly, 'The Jesuit Mission Stations ...', p.59, footnote 60 .

${ }^{18}$ Mackillop, D., 'Anthropological Notes on the Aboriginal Tribes of the Daly River', Transactions of the Royal Society of South Australia, 17, I892-3, 254-64, p. 262.
19. Harley, K, A Guide to the Management of Mimosa Pigra, CSIRO, Canberra, I992, p. II.

${ }^{20}$ Kristen, A., Aboriginal Language, Ms., I899, p. 197 .

${ }^{21}$ Kristen, Aboriginal Language, p.Ig8.

${ }^{22}$ Mackillop, 'Anthropological notes ...', p. 26I.

${ }^{23}$ There is a vast literature on this subject; I am attempting briefly to summarise a great deal of insight, as space does not allow a full examination of all of it. Compare Fabian, J., 'The Anthropology of Religious Movements: From explanation to interpretation', Social Research, 46, I979, 4-35; Fernandez, J., 'On the Notion of Religious Movements', Social Research, 46, 1979, 36-62 and Wagner, $\mathrm{R}$, 'The Talk of Koriki: A Daribi contact cult', Social Research, 46, 1979, 140-165. Koepping, K, Nativistic Movements in Aboriginal Australia: Creative adjustment, protest or regeneration of tradition?', in Swain \& Rose, Aboriginal Australians and Christian Missions, pp. 397-412, provides an overview of the Australian literature to date. Swain, T., $A$ Place for Strangers, Cambridge University Press, Cambridge, I 993 , pp. II -I $^{-1} 5^{8}$ takes up these issues.

${ }^{24} 0$ O'Kelly ('The Jesuit Mission Stations ...', p. 63) writes that 'by I 899 many factors were converging, and only a large natural reversal was needed to ensure the end of the whole Jesuit mission in the north'. The 1899 flood was just such a large natural reversal.

${ }^{25}$ Forrest, The Spirit of the Daly, p. 33.

${ }^{26}$ This is discussed in R. Alford, 'The Douglas/ Daly Region: A historical overview to I9oo', Report prepared for the National Trust of Australia, Northern Territory, 1989 , P. $5^{2}$.

${ }^{27}$ See Stanner, 'Continuity and Change ...' and Stanner, 'Durmugam ....'.

${ }^{28}$ Stanner, 'Continuity and Change ...', p. $5^{6}$.

${ }^{29}$ Stanner, 'Continuity and Change ...' pp. 55־56. 
${ }^{30}$ Stanner, 'Durmugam ...', p. 84 .

${ }^{31}$ Stanner's analysis lays the ground for his discussion of the introduction of the 'AllMother' religious movement from the Victoria River valley. Swain (A Place for Strangers) takes up all these issues in great detail.

${ }^{32} \mathrm{He}$ had been one of Stanner's main informants as well, and Stanner (Stanner, 'Durmugam ...', p. 88) described him as 'the most intelligent and detached Aboriginal I have known'. If my identification is correct, he was a young man when the mission was there. Fr Kristen spoke well of a young man named Matthew who is probably the same person.

${ }_{33}$ Berndt, R, 'Surviving Influence of Mission Contact on the Daly River, Northern Territory of Australia', Neue Zeitschrift für Missionswissenschaft/Nouvelle Revue de science missionaire, 8, 1952, I-20, pp. 8-9.

${ }^{34}$ See D. Rose, Dingo Makes Us Human; Life and land in an Australian Aboriginal culture, Cambridge University Press, 1992 and 'Ned. Kelly Died for our Sins', Oceania, 65 (2), 1995, 175-86 and Swain, A Place for Strangers. See K. Burridge, Mambu: A study of Melanesian cargo movements and their ideological background, Harper \& Row, New York, 1960 for a classic study.
${ }_{35}$ See H. Petri \& G. Petri-Odermann, 'Stability and Change: Present-day historic aspects among Australian Aborigines', in R. Berndt (ed.),Australian AboriginalAnthropology: Modern studies in the social anthropology of the Australian Aborigines, University of Western Australian Press, Nedlands, 1970, and 'A Nativistic and Millenarian Movement in North West Australia', in Swain \& Rose, Aboriginal Australians, pp. 39г-396.

${ }^{36}$ Petri \& Petri-Odermann, 'Stability and Change ...', p. $25^{8}$.

${ }_{37}$ Petri \& Petri-Odermann, 'Stability and Change ...', p. 266.

${ }^{38}$ See Stanner, 'Durmugam ...' and $O n$ Aboriginal Religion, Oceania Monograph 36 , I989, University of Sydney, Sydney.

39 Swain (A Place for Strangers) provides extensive discussion of paths of portions of the cult and its relation to other cults.

$4^{\circ}$ Petri \& Petri-Odermann, 'Stability and Change ..., p. 263 .

${ }_{4}^{4}$ Lack of entries in the early years represents the hastiness of the diary entries rather than a lack of reliance on bush tucker. 